\title{
Technological measures to enhance efficiency of mining ore from stopes applying self-propelled equipment
}

\author{
Mykola Stupnik ${ }^{1}$, Vsevolod Kalinichenko ${ }^{1, *}$, Olena Kalinichenko ${ }^{1}$, and Alexey Pochtarev ${ }^{2}$ \\ ${ }^{1}$ Kryvyi Rih National University, Department of Underground Mining of Useful Mineral Deposits, 11 Vitalii Matusevysch Str., Kryvyi \\ Rih, 50027, Ukraine \\ ${ }^{2}$ LAMET s.r.o., Bellova 3, 04001 Košice office: Rozvojovó 2 A, Slovakia
}

\begin{abstract}
The work analyzes current technologies of ore mining applying self-propelled equipment in underground conditions; studies practices of using the equipment in general and for broken ore transportation only; considers performance of mining enterprises in similar mining-geological and miningtechnical conditions; analyzes and generalizes causes of high ore loss and dilution rates in underground mining in Kryvyi Rih iron ore basin, thus revealing a problem of providing high efficiency and increased ore extraction with minimal quality deterioration. Marketable ore production is affected by decreased quality and high broken ore losses. Incomplete balance ore extraction when breaking and drawing ore from the stope results in deterioration of mining indices. Ore dilution with waste rocks leads to decreased ore content in the mined mass as compared with that in the ore massif. The research enables development and substantiation of the rational technology of ore drawing and transportation as well as designing a new structure of the loading face to ensure increase of the drawn ore quality indices.
\end{abstract}

\section{Introduction}

In Kryvyi Rih iron ore basin, iron ores have been mined for over 150 years [1,2,6,7]. At first, mining operations were performed in open pits and later - in underground mines. First underground mines were only several dozens of meters deep. Main equipment applied was a pickaxe for breaking and horses for ore transportation.

Nowadays, underground mines are more technologically developed, efficient and secure. Complete mechanization of stoping, namely principal and auxiliary processes, has become the main trend of their development [6,37-39].

At present, a high level of stoping mechanization is demonstrated by foreign mines which are more technologically developed than national ones due to the fact that complex implementation of self-propelled equipment as well as mechanization of technological processes started there in the middle of the $20^{\text {th }}$ century. Implementation of self-propelled equipment and mechanization had a comprehensive character $[6,7,40,41]$.

In Ukraine, introduction of self-propelled equipment was not large-scale. In the Soviet Union, this type of equipment was mainly introduced at uranium deposits and, to some extent, at the ZZRK underground mines [7,42-44].

In Kryvyi Rih, self-propelled equipment was used on a trial basis in 1980s-1990s. Its implementation at Kryvbas underground mines was a forced decision caused by the fact that obsolete machines were not able to provide high-technology mining. This necessitated implementation of advanced underground mines' practices $[1,2,45,46]$.

\section{Methods}

The research aims to study and enhance basic stoping processes, develop technological measures to increase efficiency of mining ore from stopes applying selfpropelled equipment.

To reach the set objective, the following methods are used:

- analysis and study of underground operations with applied self-propelled equipment;

- enhancement of drilling and blasting operations applying self-propelled equipment;

- development of efficient structures of the draw level when applying load-haul- machines;

- enhancement of stoping methods and technologies when applying self-propelled equipment at Kryvbas underground mines.

\section{Results and Discussion}

In mining ore deposits by underground methods, all the underground mining operations are divided into main and auxiliary ones [1-4].

Main underground operations include: ore breaking, broken ore drawing, transportation and loading, rock pressure control.

\footnotetext{
* Corresponding author: kalinichenko@knu.edu.ua
} 
At present, one of the most widely applied schemes consists in breaking ore by vertical blasthole rings on the vertical compensation space [4-8]. As a rule, it is used for ores with insufficient stability of horizontal, or even inclined, exposures of compensation rooms [1,47,49,50].

Here, blasthole rings are drilled from drill drifts. Ore is broken by layers with a millisecond delay between the adjacent layers necessary for forming additionnal exposure areas [2,12,48,51].

People, materials and equiment are transported along the block raise.

In ores of medium and over medium hardness and stability where significant exposures may occur, breaking can be performed on the horizontal compensation space, or the horizontal undercut.

At this breaking scheme, vertical blasthole rings are drilled from drill orts. To clearly contour the stope, drill orts are driven on the block boundaries. Ore is broken on the horizontal undercut. Primarily, blastholes of the lower layer are broken, then blastholes of the overlying level with a millisecond delay and so on bottom up $[1,13,52,53]$.

In case of insufficiently stable iron ores with no horizontal exposures and with the vertical compensation space being impossible due to technical reasons (e.g. insufficient dip angle and ore body thickness), there are applied schemes of breaking with vertical blasthole rings on the inclined compensation space $[6,7,9,10]$.

The suggested scheme of drilling the block is applied in similar conditions. Its application is mainly aimed at decreasing impact of detonation products on workings of the draw level. In addition, the inclined exposure of the compensation room is more stable than the horizontal one when forming the horizontal undercut. The inclined compensation space is formed for the full width of the stope (panel). Then from the drill ort (drift), vertical blasthole rings are drilled and broken on the inclined undercut [43,54-56].

Breaking is performed in sequence starting from the lower row of boreholes. To reduce the impact blow of the broken ore on workings of the receiving level, part of the broken but not drawn ore is left on the draw level to create a kind of cushion that reduces negative impacts of detonation products on workings of the receiving level. With the same purpose, adjacent ore layers are broken with a millisecond delay.

Historically, application of self-propelled load-haul machines started with their introduction at foreign mines in the middle of the XX century [11-14].

When choosing parameters of self-propelled equipment, it is necessary to consider technological tasks first. It is its reliability, not price, that matters.

For Kryvbas, these factors are a problem, too, that requires immediate study and solution. According to the research data $[2,13,15,16]$, the value of a diesel machine is 1.5 -fold less than that of an electric one with similar characteristics.

However, comparison of traditional mining technologies and those applying self-propelled equipment speaks in favor of the latter. The authors of [12,17-19] state that with self-propelled equipment the average monthly meterage per syndicate is $160-170 \mathrm{~m}$, a drifter's efficiency being $9 \mathrm{~m}$. Yet, at Kryvbas, monthly crosscut driving does not officially exceed $70 \mathrm{~m}$ according to official designs. This is a very low rate even for traditional drifting methods. Application of self-propelled equipment can help accelerate it.

So, selection of a technology of driving workings is of great importance. Choice of highly efficient machinery and technology is conditioned by both mining and geological conditions and required rates of drifting operations and their costs.

Main mining and geological factors include: ore rock hardness and stability, deposit dimensions along the strike, dip and thickness, deposit morphology, hydrogeological conditions, sometimes gas conditions, explosion risks, spontaneous ignition, radioactivity, etc.

At present, Kryvbas has started the second experiment of introducing self-propelled machinery in underground conditions. Let us consider the case of the underground mine "Oktiabrskaya", the PJSC "Kryvbaszalizrudkom", where the ore body "Osnovnyi" is mined applying selfpropelled equipment in compliance with the "Project of development and stoping operations in the block between axes $45-50$ on the level 1190/2265 m".

The ore body site within these axes is situated in the central part of the field of the underground mine "Oktiabrskaya" and limited to rocks of the V ferruginous and V schistose stratigraphic horizons.

The deposit is represented by the seam-like ore body which is uniform along the strike and weakly varying to the dip with inter-mineral impurities. Horizontal thickness of the ore body varies within 15-25 m. The ore body dip varies from $46^{\circ}$ to $50^{\circ}$. Its dimensions and shape refer the ore body to group "I", subgroup "b". Required prospecting intervals are $12-15 \mathrm{~m}$ along the strike, 25-30 $\mathrm{m}$ to the dip.

This part of the deposit is represented by: martite ore of the $\mathrm{V}$ ferruginous horizon, steel blue, fine-grained, thin-layered, badly fractured, with hardness of 5-7 and low stability; red dirt and martite ore of the $\mathrm{V}$ ferruginous horizon, grey-brown, represented by alternation of martite layers and dirt bands, of medium bedded structure, badly fractured, with hardness of 5-6 and low stability; red dirt of the $\mathrm{V}$ schistose horizon, dark-brown, coarselystratified, badly fractured, with hardness of 4-6 and low stability. Due to their instability, large hang-ups and rockfalls are possible. The ores do not tend to stick or drift, they are not rock-bump hazardous, cavities are not expected [15,57-59].

Many researchers note that mining enterprises use various type-dimensions of self-propelled machines. Main types of mining and transportation machines are used for mechanizing principal mining processes $[13,20$ 22]. Efficient haulage length makes $250-300 \mathrm{~m}$. The haulage workings dip is $10-15^{\circ}$.

Most of sources mention dip angles of $10-15^{\circ}$. In our opinion, such angles are borderline for now. The technological radius of roundings is $8-12 \mathrm{~m}$.

As a rule, self-propelled load-haul machines are used in ore underground mines for preparatory operations and stoping.

At present, at underground mines of Kryvbas, broken ore is transported in stopes by scraper winches. They are 
also used when driving horizontal and inclined workings, especially on sublevels.

When it is not expedient to use scraper winches, selfpropelled equipment is applied, e.g. on main haulage levels.

Scraper winches are obviously more advantageous in loading and hauling broken ore due to their relative structural simplicity and reliability in complicated mining and geological conditions.

Disadvantages of scraper winches include low efficiency and restricted haulage distance as well as quick rope wear and insufficient mechanization of operations.

For conditions of the underground mine "Oktiabrskaya", scraper haulage is an obsolete technology that does not allow implementation of innovative ones and, therefore, decrease of mining costs.

Scraper haulage operations mechanization is beneath criticism.

That is why, mechanization of underground mining processes require self-propelled machinery for most difficult and labor-intensive operations. At advanced mines, this type of equipment is used for less laborintensive auxiliary processes.

Highly efficient loading machines with large bucket capacity are used for mining large deposits.

Swedish mines, which are the most advanced in Europe, prove expediency and high efficiency of applying SCOOPTRAM to underground stoping operations.

The problem of enhancement of leading mines with the most promising mining systems applying selfpropelled load-haul machinery is considered in [23-26].

Most advanced mining countries of the world tend to change over to stoping systems with backfilling of the mined space with a solidifying mixture. Room-and-pillar systems with backfilling are the most promising ones. The systems enable undisturbed daylight surfaces and enhanced environment due to possible disposal of mining wastes in dead areas of underground mines.

Modern load-haul machinery is often equipped with remote control systems. Remote control stations can be located at any distance from the place of mining operations. Automated operation of self-propelled loadhaul equipment is applied at underground mines of South Africa.

Technologies of remote control application are described in many works [6,12,27,28, etc.]. Remote control of self-propelled machinery is implemented at advanced mining enterprises, including broken ore loading and transportation to discharge points.

Productivity of load-haul machines depends on their parameters and may reach $350-400 \mathrm{t} / \mathrm{h}$ with transportation for up to $50 \mathrm{~m}$.

At world's advanced underground mines, processes of ore loading and haulage are automated with modern equipment with dedicated hardware and software, thus increasing efficiency of self-propelled mining machines. Here, a mining engineer's task consists in safe, efficient and profitable delivery of useful minerals to the daylight surface.

Describes use of underground haulers with $50 \mathrm{t}$ capacity in gold mining. The authors stress the necessity of implementing high-level mechanization of all ore mining operations [29-32]. Thus, according to the authors, the tunneling speed of up to $150 \mathrm{~m} / \mathrm{month}$ is achieved due to application of three "Boomer" drilling rigs. The authors note that the latest models of the rigs are shortened from $4.2 \mathrm{~m}$ to $3 \mathrm{~m}$. This enables the rigs to drill anchor holes in roofs with subsequent anchoring.

It should be noted that in conditions of highly intensive work, maintainability of mining equipment and ease of maintenance of self-propelled mining machines are of great importance.

Let us select and substantiate rational stoping parameters for sublevel-and-room mining at the $\mathrm{u} / \mathrm{m}$ "Oktiabrskaya", the PJSC "KZRK". Considering mining and geological conditions of the ore body "Osnovnyi", physical and mechanical properties of ore and country rock, the sublevel-and-room mining system is accepted for mining the ore body "Osnovnyi" of the $\mathrm{u} / \mathrm{m}$ "Oktiabrskaya" minefield. Ore breaking is performed by vertical blasthole rings on the vertical slot. The subleveland-room mining system is designed for use of selfpropelled mining machinery.

The input data for calculating block geometry are given in Table 1.

Table 1. Input data for calculating block parameters

\begin{tabular}{|c|l|c|}
\hline No. & \multicolumn{1}{|c|}{ Input data } & Parameters \\
\hline 1 & Ore body class & II \\
\hline 2 & Order of priority & I \\
\hline 3 & Ore hardness, average & 5.86 \\
\hline 4 & Hanging wall ore hardness & $8-10$ \\
\hline 5 & Ore body dip angle, degrees & $42-50$ \\
\hline 6 & Horizontal thickness, m, average & 23 \\
\hline 7 & Normal thickness, m, average & 18 \\
\hline 8 & Mining depth, $m$ & 1220 \\
\hline 9 & Sublevel height, $m$ & 40 \\
\hline 10 & Compensation room life & 1.1 \\
\hline
\end{tabular}

To determine geometry of the sublevel-and-room system, the following conventional signs are accepted:

$\mathrm{H}_{\Gamma}$ and $\mathrm{H}_{\mathrm{B}}$ are the depth of horizontal exposures (crown) and vertical exposures (intervening pillars), $\mathrm{m}$;

$f_{p}$ and $f_{\text {пा }}$ are ore hardness and rock hardness coefficients respectively;

$m_{\Gamma}^{0}$ is the boundary value of the equivalent span of the horizontal exposure in the stope, life of which in the set mining and geological conditions makes $t$ months, $\mathrm{m}$;

$\mathrm{t}$ is the exposure life;

$m_{\mathrm{B}}^{0}$ is the boundary value of the equivalent span of the vertical exposure in the stope, life of which in the set mining and geological conditions makes $t$ months, $\mathrm{m}$;

$\eta_{1}$ and $\eta_{2}$ are the coefficients considering time impacts on stability of exposures and pillars;

$\eta_{3}$ is the coefficient describing relations between boundary values of equivalent spans of horizontal and vertical exposures;

$\ell_{\mathrm{H}}^{0}$ is the boundary value of the equivalent span of the inclined exposure of the hanging wall rocks in the stope, life of which in the set mining and geological conditions makes $\mathrm{t}$ months, $\mathrm{m}$;

$\mathrm{A}_{\mathrm{H}}^{0}, \mathrm{~A}_{\mathrm{I}}^{0}, \mathrm{~A}_{\mathrm{P}}^{0}$ are the boundary values of dimensionless functional characteristics for determining horizontal (inclined) thickness of the crown and width of the 
intervening pillar, life of which in the set mining and geological conditions makes t months.

Let us determine boundary values of calculated functional characteristics: with the mining depth $\mathrm{H}_{\Gamma}=$ $1180 \mathrm{~m}$ and hardness $\mathrm{f}_{\mathrm{p}}=6 ; m_{\mathrm{r}}^{0}=15.3 \mathrm{~m}$ at $t=$ 6 months.

At $t=2$ months and $\eta_{1}=1.24$ (according to the chart by curve 1), Fig. 1:

By the formula:

$$
m_{\Gamma}^{0}=m_{\Gamma}^{0} \cdot \eta_{1}=15.3 \cdot 1.24=19 \mathrm{~m}
$$

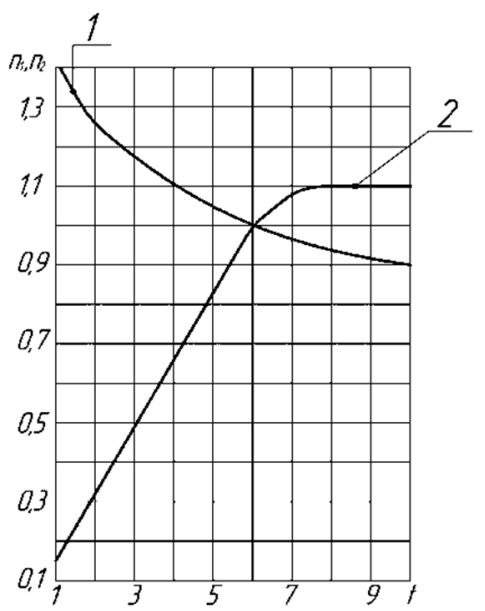

Fig. 1. Dependency of the coefficients $\eta_{1}$ and $\eta_{2}$ on life of exposures and pillars.

For $H_{2}=1180 \mathrm{~m}$ and $f_{p}=6$ (according to the chart, Fig. 2):

$$
\mathrm{A}_{\Pi \mathrm{P}}^{0}=1.28 \text { at } t=6 \text { months }
$$

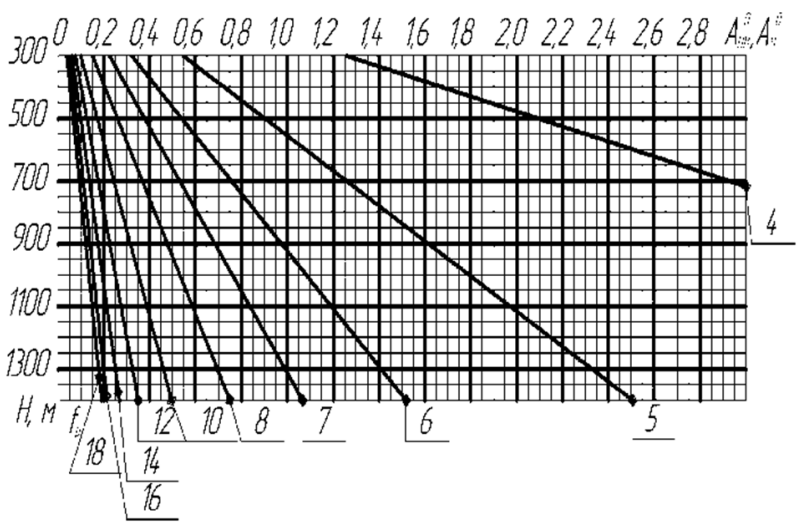

Fig. 2. Dependency of the boundary values of calculated functional characteristics $A_{Ц}^{0}$ and $A_{\Pi \mathrm{H}}^{0}$ on the mining depth at $\mathrm{t}=$ 6 months.

At $t=2$ months and $\eta_{2}=0.32$ (by curve 2)

By the formula:

$$
\mathrm{A}_{\Pi \mathrm{H}}^{0}=\eta_{2} \cdot \mathrm{A}_{\Pi \mathrm{H}}^{0}=0.32 \cdot 1.28=0.41
$$

To determine $m_{\mathrm{B}}^{0}$ according to the formula:

$$
m_{\mathrm{B}}^{0}=\eta_{3} \cdot m_{\Gamma}^{0}
$$

we find $m_{\mathrm{r}}^{0}$ for $\mathrm{H}_{\mathrm{B}}=1200 \mathrm{~m}$ and $\mathrm{f}_{\mathrm{p}}=6$ at $t=$ 6 months

$$
m_{\Gamma}^{0}=15.1 \mathrm{~m}
$$

At $t=6$ months, at $t=2$ months and $\eta_{1}=1.24$

$$
m_{\Gamma}^{0}=\eta_{1} \cdot m_{\Gamma}^{0}=1.24 \cdot 15.1=18.7 \mathrm{~m}
$$

$\eta_{3}=1.28$ then

$$
m_{\mathrm{B}}^{0}=1.28 \cdot 18.7=24 \mathrm{~m}
$$

To determine $\ell_{\mathrm{H}}^{0}$ by the expression:

$$
\ell_{\mathrm{H}}^{0}=1.35 \cdot m_{\Gamma}^{0}
$$

we find $m_{\Gamma}^{0}$ for $\mathrm{H}_{\mathrm{B}}=1200 \mathrm{~m}$ and $\mathrm{f}_{\mathrm{n \Pi}}=9$. From the chart $m_{\Gamma}^{0}=20.5 \mathrm{~m}$ at $t=6$ months. At $t=2$ months and $\eta_{1}=$ 1.24

$$
\begin{gathered}
m_{\Gamma}^{0}=\eta_{1} \cdot m_{\Gamma}^{0}=1.24 \cdot 20.5=25.42 \mathrm{~m} \\
\ell_{\mathrm{H}}^{0}=1.35 \cdot 25.42=34.3 \mathrm{~m}
\end{gathered}
$$

By the formula:

$$
\mathrm{A}_{\Pi}^{0}=\frac{\mathrm{A}_{\Pi \mathrm{H}}^{0}}{0.75}=\frac{0.41}{0.75}=0.55
$$

we determine geometric parameters of the mining system.

Dimensions of the stope along the strike are calculated applying the found value $m_{\Gamma}^{0}=19 \mathrm{~m}$ and the known value of the horizontal thickness $\mathrm{M}_{\Gamma}=23 \mathrm{~m}$ from the left part of the chart $\mathrm{a}=34 \mathrm{~m}$; let us assume $\mathrm{a}=30 \mathrm{~m}$.

Dimensions of the stope to the dip are calculated applying the found value $m_{\mathrm{B}}^{0}=24 \mathrm{~m}$ and the known value of the normal thickness $\mathrm{M}_{\mathrm{H}}=18 \mathrm{~m}$; $\mathrm{B}=\infty$.

The equivalent span of the hanging wall exposures in the stope is determined by the expression:

$$
\ell_{\mathrm{H}}=\frac{\mathrm{a} \cdot \mathrm{B}}{\sqrt{\mathrm{a}^{2}+\mathrm{B}^{2}}}=\frac{30 \cdot 23}{\sqrt{30^{2}+23^{2}}}=\frac{690}{37.8}=18.25 \mathrm{~m}
$$

On comparing it with $\ell_{\mathrm{H}}^{0}=34.3 \mathrm{~m}$, we obtain $18.25<$ 34.3; thus, the parameters $a$ and 8 remain unchanged.

In this case, sublevel-and-room and level-and-room mining systems can be applied.

According to the functional characteristics of the designed block, the crown thickness is accepted equal to $h=15 \mathrm{~m}$.

As at the level of $1220 \mathrm{~m}$ the block is mined first, the width of the pillar is not determined.

The obtained dimensions of the constructive elements of the system are given in Table 2.

Table 2. Dimensions of the constructive elements of the sublevel-and-room system.

\begin{tabular}{|l|c|c|}
\hline \multicolumn{1}{|c|}{ Block elements } & Accepted & alculated \\
\hline Stope dimensions along the strike & 30 & 34 \\
\hline Stope dimensions to the dip & 23 & $\infty$ \\
\hline Trench undercut width, m & 30 & - \\
\hline Compensation space volume, m3 & 2632 & - \\
\hline Stope volume, m3 & 10526 & - \\
\hline Hanging wall rock exposure area, m2 & 690 & 782 \\
\hline $\begin{array}{l}\text { Ore massif thickness above stope } \\
\text { (crown), } \mathrm{m}\end{array}$ & 15 & 15 \\
\hline
\end{tabular}

For drilling, it is expedient to use self-propelled longhole drilling machines SIMBA of Atlas Copco. The massif is broken by vertical blasthole rings on the horizontal compensation space (trench undercut), Fig. 3.

According to the suggested circuit and considering the ore body thickness, which is $20-25 \mathrm{~m}$, it is reasonable to start drilling from the drill drift driven in the footwall rock.

After forming the trench undercut, part of the broken ore is left on the draw level. The broken ore will further serve as a compensation cushion to prevent workings of the draw level from failure.

Ore is broken by layers with a millisecond delay between the adjacent layers. 
Drilling and blasting parameters are calculated in compliance with the instructions [33-36].

Drilling and blasting parameters for mining a block with average ore hardness $f=6$ are given in Table 3 .

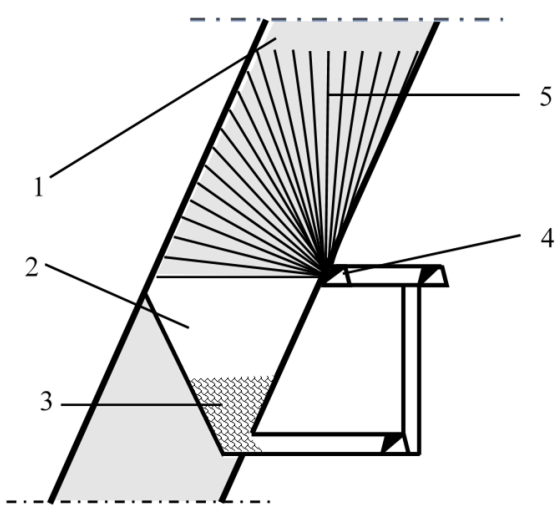

Fig. 3. The circuit of breaking the massif by vertical blasthole rings on the horizontal compensation space (trench undercut): 1 - the ore body, 2 - the trench undercut, 3 - the broken ore cushion, 4 - the drill drift, 5 - the blasthole ring.

The blasting and drilling parameters are calculated based on the practice of the underground mine "Oktiabrskaya". The LLR equals $3 \mathrm{~m}$. The distance between hole ends is $3.5 \mathrm{~m}$. In our opinion, such parameters will decrease oversize yield and losses of explosives for secondary fragmentation.

Table 3 Drilling and blasting parameters for mining the block under study.

\begin{tabular}{|l|c|c|c|}
\hline \multicolumn{1}{|c|}{ Indicator } & $\begin{array}{c}\text { Units of } \\
\text { measure- } \\
\text { ment }\end{array}$ & $\begin{array}{c}\text { By rock } \\
\text { hardness }\end{array}$ & $\begin{array}{c}\text { Conside- } \\
\text { ring stress } \\
\text { state }\end{array}$ \\
\hline Rock blasting indicator & $\mathrm{C}_{0}$ & 36.867 & 34.964 \\
\hline LLR value & $\mathrm{m}$ & 3.5 & 3.38 \\
\hline $\begin{array}{l}\text { Distance between blasthole } \\
\text { ends }\end{array}$ & $\mathrm{m}$ & 3.85 & 3.65 \\
\hline $\begin{array}{l}\text { Boundary consumption of } \\
\text { explosives for breaking }\end{array}$ & $\mathrm{kg} / \mathrm{t}$ & 0.318 & 0.302 \\
\hline $\begin{array}{l}\text { Diameter of average ore } \\
\text { fragment (fragmentation } \\
\text { quality) }\end{array}$ & $\mathrm{m}$ & 0.184 & 0.178 \\
\hline $\begin{array}{l}\text { Oversize yield } \\
\text { Specific consumption of } \\
\text { explosives for secondary } \\
\text { fragmentation }\end{array}$ & $\mathrm{g} / \mathrm{t}$ & 75 & 74 \\
\hline
\end{tabular}

The process water from drilling blastholes is gathered in the sludge trap of the drill drift. Then, it goes in metal and rubberized pipes of 2-3 inches in diameter to the sludge settler of the access ort where it is clarified. The clarified water runs to the drainage ditch of the haulage ort and then to the mineshaft into the water reservoir.

When drilling the ore massif above the trench undercut level from the drill drift, the process water from drilling blastholes is gathered in the sludge settler in access orts above the area of blasthole drilling for clarification. The clarified water is drained into the drainage ditch of the haulage drift and then to the mineshaft into the water reservoir.

Two versions of the rational draw level structure are suggested.
The first version of the draw level with application of modern load-haul machines for transporting broken ore is developed for the ore body thickness 1 of over $25-30 \mathrm{~m}$, Fig. 4.
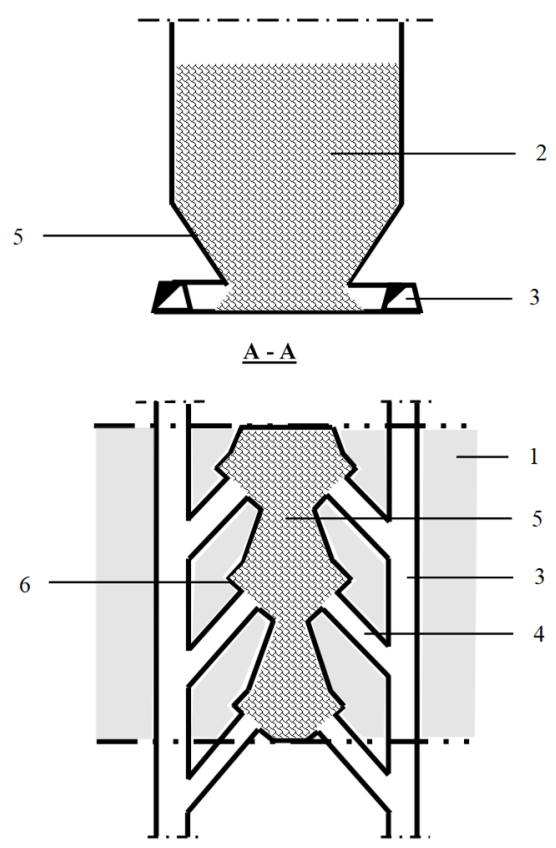

Fig. 4. The draw level structure for the ore body thickness of over 25-30 m with application of modern load-haul machinery for broken ore transportation: 1 - the ore body, 2 - the stope, 3 - the supply ort, 4 - the loading face, 5 - the trench undercut, 6 - the frontal loading face.

In this case, the stope 2 is located across the strike.

Block supply orts 3 from which loading faces 4 are driven at the angle to the stope are located on the boundaries of the block.

Block undercutting is trench. The trench 5 is created on the transportation level across the strike. The trench width should provide broken ore loading from the opposite loading faces.

The main disadvantage of loading broken ore from loading faces driven at the angle is that the bucket goes into the broken ore at the angle as well, thus deteriorating the bucket fill factor and resulting in one side wear of the bucket.

To eliminate this disadvantage, we suggest formation of the loading face 6 in the way that enables frontal fill of the bucket through its entering the muckpile perpendicularly.

The other option of the draw level with application of modern load-haul machines for transporting the broken ore is developed for the ore body thickness 1 of less than 25-30 m, Fig. 5. In this case, the stope 2 is located along the strike.

Block undercutting is trench. The trench 3 is created along the strike for the full width of the stope. The trench height depends on the thickness of the ore body and the angle of the trench slope dip which should provide broken ore rolling down the trench slopes by gravity.

In the footwall of the block, the block supply drift 4 is driven from which loading faces 5 are driven at the angle to the stope. 

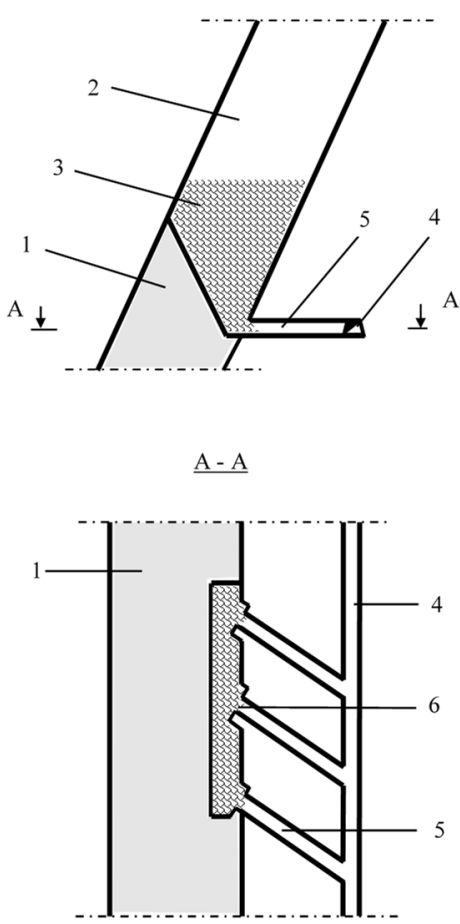

Fig. 5. The draw level structure for the ore body thickness of less than 25-30 m with application of modern load-haul machinery for broken ore transportation: 1 - the ore body, 2 - the stope, 3 - the trench undercut, 4 - the supply drift, 5 - the loading face, 6 - the frontal loading face.

The frontal loading face 6 is formed to enable frontal loading of the bucket through its entering the muckpile perpendicularly.

Considering the fact that the number of blocks at Kryvbas underground mines applying self-propelled equipment is limited, it is recommended to use selfpropelled load-haul machines, previously used to drive workings, for broken ore transportation. With this purpose, we plan to use ST1030 SCOOPTRAM of Atlas Copco.

Ore can be discharged into both ore passes and electric railway haulage cars.

\section{Conclusions}

The work presents analysis of literature sources dealing with application of self-propelled machinery in stoping in general and for underground mining operations only and considers practices of mining enterprises' performance in similar conditions.

Geometry of block elements at stoping applying the sublevel-and-room system in compliance with the instructions "Determination and control of permissible dimensions of structural elements of mining systems at Kryvbas mines" is calculated to ensure stability of stopes throughout the block life.

The article suggests efficient versions of drilling the massif and determines their advantages and disadvantages.

The main disadvantage of loading the broken ore from loading faces driven at the angle is that the bucket of the machine enters the muckpile at the angle as well, thus deteriorating the bucket fill factor and resulting in one side wear of the bucket.

To eliminate this disadvantage, the authors suggest new versions of the draw level structure with formation of the loading face in the way that enables frontal fill of the bucket through its entering the muckpile perpendicularly and provide drawings of the versions.

The suggested enhanced technology of stoping considers the recommended parameters of underground operations on the basis of the research conducted.

The conducted research proves the viability of the developed technology and enable recommending its implementation.

\section{References}

1. M. Stupnik, O. Kalinichenko, V. Kalinichenko, S. Pysmennyi, O. Morhun, Choice and substantiation of stable crown shapes in deep-level iron ore mining. MMD. 12(4), 56-62 (2018). doi:10.15407/mining12.04.056.

2. M. Stupnik, V. Kalinichenko, Annual ScientificTechnical Colletion - Mining of Mineral Deposits 2013. 49-52 (2013)

3. O. Khomenko, A. Sudakov, Z. Malanchuk, Ye. Malanchuk, Naukovyi Visnyk Natsionalnoho Hirnychoho Universytetu. 2, 35-43 (2017)

4. M. Petlovanyi, V. Lozynskyi, S. Zubko, P. Saik, K. Sai, Rudarsko Geolosko Naftni Zbornik. 34(1), 8391 (2019). doi:10.17794/rgn.2019.1.8

5. M. Stupnik, V. Kolosov, S. Pysmennyi, K. Kovbyk, E3S Web of Conferences. 123, 01007 (2019). https://doi.org/10.1051/e3sconf/201912301007.

6. M. Stupnik, V. Kalinichenko, S. Pysmennyi, O. Kalinichenko, M. Fedko, MMD. 10(3), 46-51 (2016). doi:10.15407/mining10.03.046

7. M.I. Stupnik, V.O. Kalinichenko, O.V. Kalinichenko, I.O. Muzika, M.B. Fed'ko, S.V. Pismennyi, Metallurgical and mining industry. 7, 377-383 (2015)

8. O. Khomenko, M. Kononenko, M. Petlyovanyy, Progressive Technologies Of Coal, Coalbed Methane, And Ores Mining. 241-245 (2014). doi:10.1201/b17547-43

9. M. Petlovanyi, V. Lozynskyi, P. Saik, K. Sai, Predicting the producing well stability in the place of its curving at the underground coal seams gasification. E3S Web of Conferences. 123, 01019 (2019). doi:10.1051/e3sconf/201912301019

10. Z. Malanchuk, V. Moshynskyi, Y. Malanchuk, V Korniienko, M. Koziar, Key Engineering Materials. 844, 77-87 doi:10.4028/www.scientist.net/KEM.844.77

11. M.B. Fedko, V.A. Kolosov, S.V. Pismennyy, Ye.A. Kalinichenko, Naukovyi Visnyk Natsionalnoho Hirnychoho Universytetu. 4, 79-84 (2014) 
12. S. Pysmennyi, M. Fedko, N. Shvaher, S. Chukharev, E3S Web of Conferences. 201, 01022 (2020). doi:10.1051/e3sconf/202020101022.

13. N. Stupnik, V. Kalinichenko, Geomechanical Processes During Underground Mining - Proceedings of the School of Underground Mining, 15-17 (2012)

14. S. Pysmenniy, N. Shvager, O. Shepel, K. Kovbyk, O. Dolgikh E3S Web of Conferences, 166, 02006 (2020). doi:10.1051/e3sconf/202016602006

15. S. Pysmennyi, D. Brovko, N. Shwager, I. Kasatkina, D. Paraniuk, O. Serdiuk, Eastern-European Journal of Enterprise Technologies. 5(1(95)), 33-45 (2018). doi:10.15587/1729-4061.2018.142483

16. V. Morkun, V. Tron, Metallurgical and Mining Industry. 5, 8-10 (2014)

17. V. Morkun, N. Morkun, A. Pikilnyak, Metallurgical and Mining Industry. 2, 35-38 (2015)

18. V. Golik, V. Morkun, N. Morkun, V. Tron, Acta Mechanica et Automatica. 13(2), 113-123 (2019). doi:10.2478/ama-2019-0016

19. V. Tron, O. Tsokurenko, D. Paraniuk, I. Haponenko, E3S Web of Conferences. 123, 01037 (2019). doi:10.1051/e3sconf/201912301037

20. V. Morkun, N. Morkun, V. Tron, Metallurgical and Mining Industry. 5, 7-11 (2015)

21. V. Morkun, V. Tron, Metallurgical and Mining Industry. 6, 4-7 (2014).

22. V. Morkun, S. Tcvirkun, Metallurgical and Mining Industry. 5, 11-14 (2014)

23. V. Morkun, V. Tron, S. Goncharov, Metallurgical and Mining Industry. 2, 31-34 (2015)

24. O. Krukovskyi, V. Krukovska, E3S Web of Conferences. 109, $00043 \quad$ (2014). doi:10.1051/e3sconf/201910900043

25. V. Tron, A. Haponenko, I. Haponenko, D. Paranyuk, E3S Web of Conferences. 201, 01025 (2020). doi:10.1051/e3sconf/202020101025

26. V. Morkun, N. Morkun, A. Pikilnyak, Metallurgical and Mining Industry, 3, 28-31 (2014)

27. Ye. Malanchuk, V. Korniienko, L. Malanchuk, V. Zaiets, E3S Web of Conferences. 211, 01036 (2020). doi:10.1051/e3sconf/202020101036

28. O. Krukovskyi, V. Krukovska, Yu. Vynohradov, MMD. 11(2), 21-27. (2017). doi:10.15407/mining11.02.021

29. V. Tron, O. Tsokurenko, D. Paraniuk, I. Haponenko, E3S Web of Conferences. 123, 01037 (2019). doi:10.1051/e3sconf/201912301037

30. R.O. Dychkovskyi, V.H. Lozynskyi, P.B. Saik, M.V. Petlovanyi, Ye.Z. Malanchuk, Z.R. Malanchuk, Archives of Civil and Mechanical Engineering, 18(4), 1183-1197 doi:10.1016/j.acme.2018.01.012

(2018).

31. Z.R. Malanchuk, V.S. Moshynskyi, V.Y. Korniienko, Y.Z. Malanchuk, V.H. Lozynskyi, Naukovyi Visnyk Natsionalnoho Hirnychoho
Universytetu, $\quad 6, \quad 11-18$. $\quad$ (2019). doi:10.29202/nvngu/2019-6/2

32. Pivnyak, R. Dychkovskyi, E.C. Cabana, V. Lozynskyi, P. Saik, Key Engineering Materials, (844), 4. Trans Tech Publications Ltd., Switzerland. ISBN: $\quad 978-3-0357-1139-4 \quad$ (2020). doi:10.4028/www.scientific.net/KEM.844

33. O. Khomenko, M. Kononenko, M. Petlyovanyy, Progressive Technologies Of Coal, Coalbed Methane, And Ores Mining. 241-245 (2014). doi:10.1201/b17547-43

34. M. Petlovanyi, O. Kuzmenko, V. Lozynskyi, V. Popovych, K. Sai, P. Saik, MMD. 13(1), 24-38 (2019). doi:10.33271/mining13.01.024

35. D.V. Brovko, V.V. Khvorost, V.Yu. Tyshchenko, Naukovyi Visnyk Natsionalnoho Hirnychoho Universytetu. 4, 66-71 (2018). doi:10.29202/nvngu/2018-4/14

36. O. Khomenko, M. Kononenko, M. Petlovanyi, New Developments In Mining Engineering 2015, 265-269 (2015). doi:10.1201/b19901-47

37. V. Falshtynskyi, V. Lozynskyi, P. Saik, R. Dychkovskyi, M. Tabachenko, MMD, 10(1), 16-24 (2016). doi:10.15407/mining 10.01.016

38. S. Dineva, M. Boskovic, in J Wesseloo (ed.), Proceedings of the Eighth International Conference on Deep and High Stress Mining. Australian Centre for Geomechanics. 125-139 (2017)

39. Y. Biruk, H. Mwagalanyi, Master's thesis. Department of Civil, Environmental and Natural Resources Engineering. 74 (2010)

40. H.A. Aytashev, V.A. Isakov, H.A. Prokushev, KH.YU. Tsunzava, H.YE. Chernyshov, Hirnychyy zhurnal. 11, 31-37 (1968)

41. K. Rysbekov, D. Huayang, T. Kalybekov, M. Sandybekov, K. Idrissov, Y. Zhakypbek, G. Bakhmagambetova, Mining of Mineral Deposits. 13(3), 40-48 (2019). doi:10.33271/mining13.03.040

42. T. Kalybekov, M. Sandibekov, K. Rysbekov, Y. Zhakypbek, Substantiation of ways to reclaim the space of the previously mined-out quarries for the recreational purposes. E3S Web of Conferences. 123, 01004 (2019). doi:10.1051/e3sconf/201912301004

43. YU.P. Kaplenko, V.A. Kolosov, Mineral. 177 (2001)

44. A.D. Chernykh, I.A. Kalishevskiy, A.M. Mayevskiy, D.V. Gordin, Sích. 318 (1993)

45. D. Anastasov, N.Valkanov, L. Totev, G. Dachev, I.Mitev, 25th World Mining Congress. 1328-1336 (2018)

46. V. Korniyenko, V. Nadutyi, Y. Malanchuk, M. Yeluzakh, MMD. 14(4), 90-96 (2020). doi:10.33271/mining 14.04.090

47. D. Anastasov, At. Marinski, 22nd World Mining Congress. 1, 177-179 (2011)

48. Z. Malanchuk, V. Moshynskyi, P. Martyniuk, S. Stets, D. Galiyev, E3S Web of Conferences. 211, 01011 (2020). doi:10.1051/e3sconf/202020101011 
49. A.S. Vol'mir, Tekhniko-teoreti-cheskaya literature. 419 (1956).

50. V. Moshynskyi, Z. Malanchuk, V. Tsymbaliuk, L. Malanchuk, R. Zhomyruk, O Vasylchuk, MMD. 14(2), 95-102 (2020). doi:10.33271/mining14.02.095

51. V. Tron, A. Haponenko, I. Haponenko, D. Paranyuk, E3S Web of Conferences. 201, 01025 (2020). doi:10.1051/e3sconf/202020101025

52. Z. Malanchuk, V. Korniyenko, Ye. Malanchuk, A. Khrystyuk, M. Kozyar, E3S Web of Conferences. Volume 166, 02008 (2020). doi:10.1051/e3sconf/202016602008

53. V. Lozynskyi, P. Saik, M. Petlovanyi, K. Sai, Ye. Malanchyk, International Journal of Engineering Research in Africa. 35, 77-88 (2018). doi:10.4028/www.scientific.net/JERA.35.77

54. V. Lozynskyi, V. Medianyk, P. Saik, K. Rysbekov, M. Rudarsko Geolosko Naftni Zbornik. 35(2), 23-32 (2020). doi:10.17794/rgn.2020.2.3

55. R. Dychkovskyi, Ia. Shavarskyi, P. Saik, V. Lozynskyi, V. Falshtynskyi, E. Cabana, MMD. 14(2), 85-94 (2020). doi:10.33271/mining14.02.085

56. O. Bazaluk, M. Petlovanyi, V. Lozynskyi, S. Zubko, K. Sai, P. Saik, Sustainability, 13(2), 834 (2021). doi:10.3390/su13020834

57. O. Dolgikh, L. Dolgikh, E3S Web of Conferences 166, $03002 \quad$ (2020). doi:10.1051/e3sconf/202016603002

58. V. Tron, A. Haponenko, I. Haponenko, D. Paranyuk, E3S Web of Conferences. 201, 01025 (2020). doi:10.1051/e3sconf/202020101025

59. O. Dolgikh, L. Dolgikh, I. Kuchnerov, E3S Web of Conferences 201, $01029 \quad$ (2020). doi:10.1051/e3sconf/202020101029 